\title{
FACTORS AFFECTING RESIDENTS' SUPPORT FOR CULTURAL TOURISM DEVELOPMENT
}

\author{
Daniela Soldić Frleta \\ Jelena Đurkin Badurina
}

https://doi.org/10.20867/tosee.05.13

\begin{abstract}
Purpose - The main purpose of this paper is to find out the residents' perceptions and attitudes as well as what factors influence their support when cultural tourism development is concerned. City of Zagreb is chosen as research area as one of the most attractive continental destinations in Croatia that is hosting more and more visitors every year, so it was found necessary to find out the residents' perspective regarding this trend, particularly toward cultural tourism that has a great innovation potential. Considering the fact that cultural tourists appreciate the aspects of culture and experiences that are innovative and supported by the local population, the aim of this research is to find out the residents point of view where is tested if residents' perception of tourism impacts affect their attitude toward cultural tourism development.

Methodology - In order to obtain the residents' attitudes and opinions, an on-site-survey was carried out. The questionnaire consists of three parts collecting the residents' attitudes towards different tourism impacts, their involvement in the tourism development, as well as their sociodemographic characteristics. Data analysis include descriptive statistics, reliability test as well as regression analyses.

Findings - Study reveal the residents' opinions regarding impacts that tourism generates when City of Zagreb is concerned. Moreover, the results provide the information regarding the differences in the residents' support towards cultural tourism development considering their sociodemographic characteristic and their perceptions towards the tourism impacts.

Contribution - The main contribution of this paper lies in the connection between residents' sociodemographic characteristics, perception of tourism impacts and support of cultural tourism development.
\end{abstract}

Keywords residents; cultural tourism; cultural offering; city of Zagreb

\section{INTRODUCTION}

The city of Zagreb, apart from being capital city, is the cultural, transport, scientific, economic and administrative centre of Croatia. Zagreb is chosen as research area as one of the most attractive continental destinations that is hosting more and more visitors every year, so it was found necessary to find out the residents' perspective regarding this trend, particularly toward cultural tourism that has a great innovation potential. Tourists' interest for Zagreb is significantly increasing during the last decade. Given the high seasonality issues that Croatian coast is facing; Zagreb represents a positive example of a year-round destination. It's popularity as a tourist destination has been rising partly due to the different international events organised throughout the year, as well as to the special Christmas Markets which have been voted the best in Europe for three years in a row. According to Croatian bureau of statistics (2018) in 2017 a total of 1.286.087 
ToSEE - Tourism in Southern and Eastern Europe, Vol. 5, pp. 641-653, 2019

D. Soldić Frleta, J. Đurkin Badurina: FACTORS AFFECTING RESIDENTS' SUPPORT FOR ...

tourists visited Zagreb, $16 \%$ more than in the previous year and more than $51 \%$ compared to 2010 .

Considering this trend of increasing number of tourists, special attention needs to be placed on their impact on the city and its residents. Residents' attitudes regarding the impacts of tourism have been a subject of research for several decades, with many contradictory results that cannot be applicable to all tourist destinations (Almeida-Garcia et al. 2015). Nowadays we are facing growing symptoms of tourism saturation with criticism often led by social movements in some popular (mainly urban) destinations; described as "overtourism" and "tourismphobia" (Milano, 2017). Therefore, identifying factors affecting residents' support for tourism development is very important for tourism research and practice. As UNWTO and IPSOS (2019) recent research shows, in order to better manage the issues arising from the growing tourism demand in urban destinations it is essential to understand resident's experiences and perceptions.

In terms of Zagreb as a bustling culture tourism destination with intensive development, over the past decades, several tourism surveys regarding tourists' attitudes towards Zagreb offering has been conducted by different institutions (Zagreb Tourist Board, 2018 and Institute for tourism, 2010). However, there is an evident lack of surveys concerning residents' perceptions and attitudes regarding tourism development and its impacts on the community.

The aim of this research is to find out the residents point of view regarding tourism, where is tested if residents' perception of economic, socio-cultural and environmental tourism impacts affects their support toward cultural tourism development in the city of Zagreb. Different sociodemographic characteristics of residents were also taken into account. Results will add to the existing body of knowledge on this specific topic, but will also be relevant for a destination management since it can assist them in their efforts to make the local community more involved in the tourism development.

\section{THEORETICAL BACKGROUND}

According to UNWTO, tourism is the world's third largest export category (UNWTO, 2018) and represents significant source of positive economic impacts for receiving areas. However, great number of research implies that tourism development does not only bring positive effects but also has a potentially negative effect on a local level (Ko and Stewart, 2002). Throughout more than thirty years of research on residents' attitudes regarding the impacts of tourism, consensus has been made on grouping tourism impacts in following groups (including positive and negative aspects): economic, sociocultural and environmental impacts (Almeida-Garcia et al. 2015).

Examples of most important (positive and negative) economic, socio-cultural and environmental tourism impacts (in terms of research on residents' perception) are listed in Table 1. 
ToSEE - Tourism in Southern and Eastern Europe, Vol. 5, pp. 641-653, 2019

D. Soldić Frleta, J. Đurkin Badurina: FACTORS AFFECTING RESIDENTS' SUPPORT FOR ...

Table 1: Summary of key research on residents' perception of positive and negative tourism impacts

\begin{tabular}{|c|c|c|c|}
\hline & Economic impacts & & Environmental impacts \\
\hline Positive & $\begin{array}{l}\text { Generating employment } \\
\text { (Choi and Sirakaya, } \\
\text { 2005; Meimand et.al., } \\
\text { 2017; Sanchéz-Cañizares } \\
\text { et al. 2014) } \\
\text { Source of income for } \\
\text { residents (Bujosa and } \\
\text { Rosselló, 2007) }\end{array}$ & $\begin{array}{l}\text { Improving the quality of } \\
\text { residents' lives, } \\
\text { community infrastructure } \\
\text { and public facilities } \\
\text { (Andreck and Vogt, } \\
2000 \text {; Meimand et.al., } \\
2017 \text { ) } \\
\text { Increased pride and } \\
\text { cultural identity (Yoon et } \\
\text { al. 2001; Sanchéz- } \\
\text { Cañizares et al. 2014) }\end{array}$ & $\begin{array}{l}\text { Help in preserving } \\
\text { natural resources } \\
\text { (Andereck } \\
\text { Nyaupane, and } \\
\text { Sanchéz-Cañizares et al. } \\
2014)\end{array}$ \\
\hline Negative & $\begin{array}{l}\text { Economic leakage (Singh } \\
\text { and Wright, 2011) } \\
\text { Increased cost of living } \\
\text { (Bujosa and Rosselló, } \\
\text { 2007;Sanchéz-Cañizares } \\
\text { et al. 2014) }\end{array}$ & $\begin{array}{l}\text { Immoral and criminal } \\
\text { behaviour; erosion of } \\
\text { traditional values (King } \\
\text { et al., 1993; Andreck et } \\
\text { al. 2005; Meimand et.al., } \\
\text { 2017) }\end{array}$ & $\begin{array}{l}\text { Pollution, rubbish, } \\
\text { overcrowding and } \\
\text { congestion (Yoon et al. } \\
\text { 2001; Andreck et al. } \\
2005) \\
\text { Environmental } \\
\text { degradation (Choi and } \\
\text { Sirakaya, 2005; Sanchéz- } \\
\text { Cañizares et al. 2014 ). }\end{array}$ \\
\hline
\end{tabular}

Table 1 lists only most common tourism impacts and only several supporting research papers are chosen among vast number of literature for each impact.

When it comes to examining the support of local residents for tourism development (main focus of this paper), based on review of existing literature, Sharpley (2014) concluded that perceived positive impacts of tourism encourages community to support tourism development, while focus on the perceived negative effects of tourism reduces residents support for tourism development. It is in line with the main assumption of Social Exchange Theory which states that if residents perceive the benefits of tourism development to outweigh the costs of the development, they will be more inclined to support tourism development (Andriotis, 2005; Jurowski et al. 1997). Also, previous research revealed that demographic variables (e.g., gender, age, and level of education) affect the perceptions of residents toward tourism development due to the differences in individual experience of the tourism impacts (McGehee and Andereck, 2004; Látková and Vogt, 2012; Rasoolimanesh et al. 2015).

Even though there has been extensive research on models of residents' support for tourism development in general and some variations related to their support to the sustainable tourism development (Choi and Sirakaya, 2005), there are scarce resources on factors influencing residents' support for cultural tourism development. This type of tourism oriented on learning, discovering, experiencing and consuming the tangible and intangible cultural attractions/products has great potential to reduce seasonality (Soldic Frleta and Smolčić Jurdana, 2018) and attract high spender categories of tourists (Ponferrada, 2015 in Richardson 2018; Cisneros- Martínez and Fernandez-Morales, 
ToSEE - Tourism in Southern and Eastern Europe, Vol. 5, pp. 641-653, 2019

D. Soldić Frleta, J. Đurkin Badurina: FACTORS AFFECTING RESIDENTS' SUPPORT FOR ...

2015). Still, without active support of local communities and its residents, it is impossible to create and successfully manage cultural tourism offer, especially in rural areas (Đurkin et al. 2018).

According to the results of several research designed with specific purpose to examine residents' attitudes toward cultural tourism, this type of tourism has mainly positive impacts on local communities. E.g. Tokarchuk, Gabriele, and Maurer (2017) find that cultural tourism flows have significant well-being benefits for residents. Also research conducted in South Korea on attitudes of residents living around the important cultural site confirmed that most of them believe that cultural tourism can contribute to urban development, image of the city, community pride and ethnic identity (Shin, 2017). Still, as suggested by Richards (2018), the dynamism of cultural tourism and rapidly changing meanings and interpretations of the term 'culture' "dictates" new research avenues, especially in the field of group dynamics, interactions between tourists and residents and residents' attitudes towards culture and culture tourism.

\section{METHODOLOGY}

This research attempted to identify the relationships between resident's demographic attributes, attitudes towards tourism impacts and their support of cultural tourism development. To examine the residents' attitudes and opinions, an on-site-survey was carried out in the city of Zagreb. The questionnaire consists of three parts collecting the residents' attitudes towards different tourism impacts, their involvement in the tourism development, as well as their socio-economic characteristics. A survey questionnaire was developed upon different previous researches indicating that the questionnaire items are derived and adopted from previous studies (Andereck and Vogt, 2000; Long and Kayat, 2011; Hanafiah et al. 2013; Meimand et al. 2017; McGehee and Andereck, 2004; Sanchéz-Cañizares et al. 2014; Yoon et al. 2001).

The collected data were analysed using the statistical package SPSS for Windows 25.0. Apart from descriptive statistics, data analysis includes reliability test and regression analyses. Descriptive analysis is used for sample profiling and reliability test using Cronbach Alpha is conducted in order to confirm the adequacy of the scales used for measuring tourism impacts. Regression analysis were made to identify the determinants of residents' support toward tourism development with emphasis on cultural offering. All respondents that were included in the survey are residents of the city of Zagreb. They were approached randomly in different places at different times during 2017 and 2018. In the end, 1373 questionnaires were collected and 1251 properly completed questionnaires were used in the analysis. 
ToSEE - Tourism in Southern and Eastern Europe, Vol. 5, pp. 641-653, 2019

D. Soldić Frleta, J. Đurkin Badurina: FACTORS AFFECTING RESIDENTS' SUPPORT FOR ...

Table 2: Respondents' profile $(\mathbf{N}=\mathbf{1 2 5 1})$

\begin{tabular}{|c|c|c|c|}
\hline Characteristic & & Frequency & Percent \\
\hline \multirow{2}{*}{ Gender } & Female & 691 & 55.2 \\
\hline & Male & 560 & 44.8 \\
\hline \multirow{4}{*}{ Education } & Elementary school & 47 & 3.8 \\
\hline & High school & 677 & 54.1 \\
\hline & Faculty & 447 & 35.7 \\
\hline & Master/PhD & 80 & 6.4 \\
\hline \multirow{8}{*}{$\begin{array}{l}\text { Average monthly } \\
\text { household income }\end{array}$} & Less than $660 €$ & 285 & 22.8 \\
\hline & $661 €-1300 €$ & 471 & 37.7 \\
\hline & $1301 €-2000 €$ & 279 & 22.3 \\
\hline & $2001 €-2600 €$ & 129 & 10.3 \\
\hline & $2601 €-3300 €$ & 33 & 2.6 \\
\hline & $3301 €-4000 €$ & 24 & 1.9 \\
\hline & $4001 €$ and more & 10 & 0.8 \\
\hline & Missing value & 19 & 1.5 \\
\hline \multirow{6}{*}{ Employment status } & Employed in tourism & 87 & 7.0 \\
\hline & Employed in other industries & 620 & 49.6 \\
\hline & unemployed & 63 & 5.0 \\
\hline & retired & 68 & 5.4 \\
\hline & student & 327 & 26.1 \\
\hline & other & 86 & 6.9 \\
\hline \multirow{3}{*}{ Age* } & $<=25$ & 454 & 36.3 \\
\hline & $26-39$ & 394 & 31.5 \\
\hline & 40 and more & 403 & 32.2 \\
\hline \multirow{3}{*}{ Length of residence $* *$} & $<=22$ & 462 & 36.9 \\
\hline & $23-31$ & 377 & 30.1 \\
\hline & 32 and more & 412 & 32.9 \\
\hline
\end{tabular}

Note: $*$ Age Mean $=34.9, \mathrm{SD}=14.70: * *$ Length of residents Mean $=29.3 ; \mathrm{SD}=13.8$

Table 2 summarise the profile of the respondents and it can be seen that the study's participants were mostly female $(55.2 \%)$ and aged on average 34.9 years. In terms of education level, majority of the respondents finished high school and faculty $(54.1 \%$ and $35.7 \%$, respectively) while those with master or $\mathrm{PhD}$ constituted $6.4 \%$ of the sample. The monthly household income of the majority of respondents $(93.1 \%)$ was below 2600 euros. A large section of the sample $(49.6 \%)$ had jobs that were not related to tourism. Respondents' length of residence in the city ranged from 1 year to 86 years with a mean of 29.3 years. 
ToSEE - Tourism in Southern and Eastern Europe, Vol. 5, pp. 641-653, 2019

D. Soldić Frleta, J. Đurkin Badurina: FACTORS AFFECTING RESIDENTS' SUPPORT FOR ...

\section{RESULTS AND DISCUSSION}

Given the fact that the main purpose of this study was to gather the resident's attitudes towards tourism impacts and their support when cultural tourism development is concerned, the respondents were asked to rate their level of agreement with the given statements related to those issues. Support for cultural development (measured by three items), as well as economic (six items), socio-cultural (six items) and environmental (4 items) tourism impact were assessed by respondents using a five-point scale ( 1 = strongly disagree; 2 = disagree; 3 = undecided; 4 = agree; 5 = strongly agree).

Cronbach's alpha used for the reliability analysis of items used for economic, sociocultural and environmental tourism impacts ranged from 0.782 to 0.784 (Table 3 ), well above the minimum that is required (0.7) (Baggio and Klobas 2011).

Table 3: Residents perception on tourism development impacts $(\mathbf{N}=\mathbf{1 2 5 1})$

\begin{tabular}{|c|c|c|c|}
\hline Impact & $\begin{array}{c}\text { Mean } \\
(\mathbf{m})\end{array}$ & $\begin{array}{c}\text { Std. } \\
\text { Deviation }\end{array}$ & $\begin{array}{l}\text { Cronbach's } \\
\text { alpha }\end{array}$ \\
\hline Economic & 3.777 & 0.69907 & 0.783 \\
\hline $\begin{array}{l}\text { Tourism has improved employment opportunities in } \\
\text { my community. }\end{array}$ & 3.98 & 0.974 & \\
\hline $\begin{array}{l}\text { Tourism has attracted more investment to my } \\
\text { community. }\end{array}$ & 4.02 & 0.955 & \\
\hline Tourism enhanced tourist expenditure. & 4.21 & 0.881 & \\
\hline $\begin{array}{l}\text { Our standard of living has increased considerably } \\
\text { because of tourism. }\end{array}$ & 3.00 & 1.201 & \\
\hline $\begin{array}{l}\text { Tourism provides economic benefits for local } \\
\text { population. }\end{array}$ & 3.56 & 1.115 & \\
\hline $\begin{array}{l}\text { Tourism provides economic benefits for local } \\
\text { businesses. }\end{array}$ & 3.90 & 0.954 & \\
\hline Socio-cultural & 3.8499 & 0.70452 & 0.784 \\
\hline $\begin{array}{l}\text { Owing to tourism development, local people now } \\
\text { have more diverse facilities and opportunities. }\end{array}$ & 3.88 & 1.011 & \\
\hline $\begin{array}{l}\text { Tourism is encouraging locals to various cultural } \\
\text { activities. }\end{array}$ & 3.59 & 1.078 & \\
\hline $\begin{array}{l}\text { Tourism promotes understanding, tolerance, } \\
\text { knowledge and exchange of cultures. }\end{array}$ & 3.68 & 1.039 & \\
\hline $\begin{array}{l}\text { Meeting tourists from different countries presents a } \\
\text { valuable experience. }\end{array}$ & 4.26 & 0.874 & \\
\hline $\begin{array}{l}\text { Tourism has a positive impact on the cultural identity } \\
\text { of our community. }\end{array}$ & 3.84 & 0.991 & \\
\hline $\begin{array}{l}\text { Tourism enhances the preservation of cultural } \\
\text { heritage. }\end{array}$ & 3.83 & 1.091 & \\
\hline Environmental & 3.5440 & 0.87475 & 0.782 \\
\hline $\begin{array}{l}\text { Tourism is a reason for the uncomfortably } \\
\text { overcrowded public places in our destination. }\end{array}$ & 3.59 & 1.173 & \\
\hline $\begin{array}{l}\text { The construction of hotels and other tourist facilities } \\
\text { destroys the natural environment. }\end{array}$ & 3.41 & 1.097 & \\
\hline Tourism causes crowds and noise. & 3.65 & 1.113 & \\
\hline Tourism is the cause of environmental pollution. & 3.53 & 1.116 & \\
\hline
\end{tabular}


ToSEE - Tourism in Southern and Eastern Europe, Vol. 5, pp. 641-653, 2019

D. Soldić Frleta, J. Đurkin Badurina: FACTORS AFFECTING RESIDENTS' SUPPORT FOR ...

As seen from the results presented in the Table 3 respondents perceive positive economic and socio-cultural tourism impact, while environment tourism impact is perceived to be negative. Similar results were obtained by Hanafiah et al. (2013), Ramseook-Munhurrun and Naidoo, (2011).

Majority of the respondents agree that tourism development increased tourist expenditure $(\mathrm{m}=4.21)$ and that it has improved employment opportunities in the community $(\mathrm{m}=$ 3.98) as well as attracted more investment to the community $(\mathrm{m}=4.02)$. In addition, respondents also agreed with the fact that tourism provides economic benefits for local businesses and local population. Such high level of perception of positive economic benefits is in line with results reported by Choi and Sirakaya (2005) and Bujosa and Rosselló (2007).

When socio-cultural tourism impact is concerned, high scores were found for degree of agreement with the statement that meeting tourists from different countries presents a valuable experience to them $(\mathrm{m}=4.26)$. Results also indicate that the respondents agreed that tourism provides more diverse facilities, opportunities and activities $(m=3.88)$. Further, they also agree that tourism has a positive impact on the community cultural identity $(m=3.84)$ and enhances the preservation of the cultural heritage $(m=3.83)$. Positive perception of above listed socio-cultural impacts is in line with findings of Yoon et al. (2001) and Andereck and Nyaupane (2011).

Lastly, respondents believe that tourism causes crowds and noise $(\mathrm{m}=3.65)$ as well as the environmental pollution $(\mathrm{m}=3.53)$. These results indicate that the community has become environmentally conscious and that the environmental aspects should be taken seriously when planning future tourism development in the city. Additionally, the respondents are perceiving that tourism is a reason for the uncomfortably overcrowded public places in Zagreb $(\mathrm{m}=3.59)$. Perceived negative impacts of tourism in terms of environment were also reported in the previous research (McGehee and Andereck, 2004; Bujosa and Rosselló, 2007).

Table 4: Support for future cultural tourism development $(\mathbf{N}=\mathbf{1 2 5 1})$

\begin{tabular}{|c|c|c|c|}
\hline & Mean & $\begin{array}{c}\text { Std. } \\
\text { Deviation }\end{array}$ & $\begin{array}{l}\text { Cronbach's } \\
\text { alpha }\end{array}$ \\
\hline Support for cultural tourism development & 4.4 & 0.713 & 0.801 \\
\hline $\begin{array}{l}\text { I support the development of cultural and / or historical } \\
\text { attractions }\end{array}$ & 4.40 & 0.810 & \\
\hline $\begin{array}{l}\text { I support the development of various cultural events and } \\
\text { programs }\end{array}$ & 4.43 & 0.810 & \\
\hline I support the development of additional cultural content & 4.27 & 0.907 & \\
\hline
\end{tabular}

When the future cultural tourism development is concerned, results indicate strong residents support $(m=4.40)$. The highest support residents are willing to provide is related to the development of various cultural events and programs $(m=4.43)$ followed by the development of the cultural and historical attractions in the city of Zagreb $(\mathrm{m}=$ 
ToSEE - Tourism in Southern and Eastern Europe, Vol. 5, pp. 641-653, 2019

D. Soldić Frleta, J. Đurkin Badurina: FACTORS AFFECTING RESIDENTS' SUPPORT FOR ...

4.40) and additional cultural contents $(m=4.27)$. These results indicate that the residents perceived cultural tourism to be very important for city of Zagreb and its' future tourism development.

For the purpose of identifying what factors determine residents' support for cultural tourism development, two regression analyses were conducted. In all analyses (Table, 5 and 6) VIF below critical value of 10 and tolerance for each explanatory variable in the three models have not detected the existence of multicollinearity (Sanchéz-Cañizares et al. 2014).

\section{Table 5: Socio-demographic factors affecting support for cultural tourism} development $(\mathrm{N}=\mathbf{1 2 5 1})$

\begin{tabular}{lccccc}
\hline Variables & Coefficients & Std. & \multirow{2}{*}{ Sig. } & \multicolumn{2}{c}{ Collinearity Statistics } \\
& B & Error & & Tolerance & VIF \\
\hline (Constant) & 4.071 & 0.088 & 0.000 & & 1.008 \\
Gender & 0.186 & 0.040 & 0.000 & 0.992 & 1.038 \\
Education & 0.059 & 0.030 & 0.051 & 0.963 & 1.009 \\
Household income & 0.000 & 0.000 & 0.006 & 0.991 & 2.078 \\
Length of residence & 0.089 & 0.034 & 0.009 & 0.481 & 2.029 \\
Age & -0.003 & 0.002 & 0.079 & 0.493 & \\
\hline
\end{tabular}

Note: $\mathrm{R}^{2}=0.033 ; \mathrm{F}(5,1244)=8.544 ; \mathrm{p}<0.01$; dependent variable: Support for future cultural tourism development; VIF - variance inflation factors

The first OLS regression analysis was performed to examine the effects of sociodemographic factors with the support for cultural tourism development (Table 5). In this case, the OLS results showed that three out of five variables turned out to be significant predictors of the residents' support for future development. Results indicate that respondents with higher income as well as those with longer length of residence in Zagreb tend to highly support the development of this type of tourism. Additionally, women are more supportive of cultural tourism development than men. On the other hand, age and education level were not found to be a statistically significant predictor of the support for cultural tourism (Table 5).

These findings contradict several previous studies having reported non-significant effects for gender on residents' perceptions (McGehee and Andereck, 2004; Wang and Pfister, 2008) as well as findings indicating that age and educational level are significant demographic factors for tourism support (Látková and Vogt, 2012; Rasoolimanesh et al. 2015 , etc.). This discrepancy could be explained by the fact that mentioned researches did not specifically examined support for cultural tourism. Also, such discrepancies could be explained by the micro environment in which the research was conducted, because tourism effects are significantly influenced by specific interactions between tourists and residents in a form of personal experience which can differ a lot from one individual to another (Oviedo-Garcia et. al. 2008). 
ToSEE - Tourism in Southern and Eastern Europe, Vol. 5, pp. 641-653, 2019

D. Soldić Frleta, J. Đurkin Badurina: FACTORS AFFECTING RESIDENTS' SUPPORT FOR ...

Table 6: Perceptions regarding tourism impacts as a support for cultural tourism development determinants $(\mathrm{N}=\mathbf{1 2 5 1})$

\begin{tabular}{lccccc}
\hline Variables & Coefficients & Std. & \multirow{2}{*}{ Sig. } & \multicolumn{2}{c}{ Collinearity Statistics } \\
& B & Error & & Tolerance & VIF \\
\hline (Constant) & 3.143 & 0.132 & 0.000 & & 1.355 \\
Economic impact & 0.073 & 0.031 & 0.019 & 0.738 & 1.333 \\
Social-cultural impact & 0.341 & 0.031 & 0.000 & 0.750 & 1.031 \\
Environmental impact & -0.104 & 0.022 & 0.000 & 0.970 & \\
\hline
\end{tabular}

Note: $\mathrm{R}^{2}=0.146 ; \mathrm{F}(3,1245)=71.117 ; \mathrm{p}<0.01$; dependent variable: Support for future cultural tourism development; VIF - variance inflation factors

The results of this study also confirm that positive attitudes toward tourism imply support for tourism development just as some authors have previously reported (Andereck and Vogt, 2000; Jurowski et al. 1997; King et al., 1993; Stylidis et al. 2014; Yoon et al. 2001). As summarised in the Table 6, positive perceptions of economic and sociocultural tourism impacts predict support for cultural tourism development. Hence those who perceived that economic and sociocultural tourism impact are positive tend to strongly support future cultural tourism development in comparison to those who don't perceive these impacts to be positive. Additionally, as expected, the negative significant relationship was found when perceptions about negative environmental tourism impacts were considered, indicating that those residents who perceive the environmental tourism impact to be negative, tend to support less future cultural tourism development.

\section{CONCLUSION}

Tourism is very complex phenomenon that depends greatly on the support of the local residents. The findings of this research reinforce the findings of the previous studies (e.g., Gursoy et al., 2010; Jurowski et al. 1997; Stylidis et al. 2014; Yoon et al. 2001), whereby residents are more likely to support tourism development if they perceive its benefits to outweigh the potential negative impacts. Moreover, the findings of this study have established significant relationships between all three groups of perceived impacts (economic, socio-cultural and environmental) and residents' support for future cultural tourism development. This result has been also identified by previous studies (e.g. Kuvan and Akan, 2005; Ramseook-Munhurrun and Naidoo, 2011) however those studies are dealing with the factors affecting tourism development in general, not cultural tourism development which is the focus and additional value of this study.

Given that the community attachment and involvement are precedents for sustainable tourism development (Lee, 2013), in order for destination to be sustainable, the goodwill and cooperation of the local community is essential (Stylidis et al. 2014). Therefore, knowing and understanding residents' opinions and factors affecting those opinions is of a great importance for local government, policy makers and businesses (Lee, 2013; Nunkoo and Gursoy, 2012). If residents are not aware of the tourism benefits, but at the same time suffering from negative impacts of tourism, strong opposition to tourism development could arise. Also, hence tourist destinations are transformed over time, residents' perceptions and their support for tourism development evolve as well (Almeida-Garcia et al. 2016), so constant analysis of attitudes of local community and 
ToSEE - Tourism in Southern and Eastern Europe, Vol. 5, pp. 641-653, 2019

D. Soldić Frleta, J. Đurkin Badurina: FACTORS AFFECTING RESIDENTS' SUPPORT FOR ...

identification of key factors influencing those attitudes is of a great importance for research and practice.

City of Zagreb has huge potential for cultural tourism development, especially in the field of event tourism. In light of the growing overtourism problem in major cities where local residents were protesting about the negative impacts of too many tourists in their neighbours, in order for tourism in Zagreb to be sustainable and to ensure that the residents perceive the benefits to be gained from tourism, greater participation by local residents in tourism initiatives is needed (Sanchéz-Cañizares et al. 2014).

It was found that the residents of the city of Zagreb perceived economic and sociocultural tourism impact to be positive while they perceived the impact of tourism on the environment in the opposite way. The results indicate that the residents are very well aware of positive as well as of negative potential tourism impacts which is a good indicator of well managed tourism destination that takes into the consideration the residents wellbeing along with the tourist satisfaction. Moreover, it was found that residents are supportive when cultural tourism is concerned. Given that the residents' support for tourism development reveals the higher likelihood for the tourism development to be sustainable (Ramseook-Munhurrun and Naidoo, 2011), these results should be taken into consideration when planning future tourism development of the city, since the success of any tourism development will not be possible if it is planned and constructed without the knowledge and support of the local residents (Yoon et al. 2001).

It is also important for city planners not to forget to continuously communicate benefits of tourism development through various marketing tools in order to maintain residents' support and collaboration (Oviedo-Garcia et. al 2008). Since research results indicated that respondents with higher income as well as those with longer length of residence in Zagreb demonstrate statistically significantly higher support to cultural tourism development, it might be useful to concentrate marketing efforts regarding promoting tourism benefits to those particular segments which tend to be less supportive towards cultural tourism development in Zagreb.

Considering the fact that cultural tourists appreciate the aspects of culture and experiences that are innovative and supported by the local population, residents need to take active role in future cultural offer development. In that way Zagreb, as a city with impressive cultural offerings, can be presented as a well-managed cultural tourism destination with highly satisfy residents, while allowing for sustainable growth

The results of this study provide tourism management with information about local residents' perceptions of tourism impacts as well as their impact on the support for cultural tourism development. It is recommended to consult these results in future planning process not just to gain residents' support for tourism but also to achieve long term sustainable development.

This research, just as any other, has certain limitations that need to be mentioned, starting from the fact that study was restricted to city of Zagreb. Thus, for generalization purposes, future research could include different destinations in order for results to be compared between them. For a more complete picture, more variables and dimensions 
ToSEE - Tourism in Southern and Eastern Europe, Vol. 5, pp. 641-653, 2019

D. Soldić Frleta, J. Đurkin Badurina: FACTORS AFFECTING RESIDENTS' SUPPORT FOR ...

could be included in the OLS models, especially those referring to the residents' attitudes towards different tourism elements (i.e. satisfaction with different tourism offering elements, involvement in decision making process relate to tourism development etc. Additionally, since residents' perceptions and their level of support tend to change in time (as a destination moves from one stage of its life cycle to the next) (Gursoy et al. 2010) and given that attitude is an intangible and dynamic in its formation (Díaz and Gutiérrez, 2010), it could be useful to conduct similar research on regular bases in order to provide longitudinal analysis of the residents' attitudes and their support when tourism in concerned, as Zagreb further develop cultural as well as other types of tourism.

\section{ACKNOWLEDGEMENTS}

This paper has been financially supported by the University of Rijeka. for project ZP UNIRI $1 / 18$.

\section{REFERENCES}

Almeida-Garcia, F., Balbuena-Vazquez, A., Cortés Macías, R. (2015), "Resident's attitudes towards the impacts of tourism”, Tourism Management Perspectives, Vol. 13, pp 33-40. https://doi.org/ 10.1016/j.tmp.2014.11.002

Almeida-Garcia, F., Balbuena-Vazquez, A., Cortes-Macias, R. (2016), "Residents' perceptions of tourism development in Benalmádena (Spain)", Tourism Management, Vol. 54, No. 3, pp. 259-274.

Andereck, K.L. and Vogt, C.A. (2000), “The Relationship between Residents' Attitudes toward Tourism and Tourism Development Options”, Journal of Travel Research, Vol. 39, No. 1., pp. 27-36. https://doi.org/10.1177/004728750003900104

Andereck, K.L., Valentine, K.M., Knopf, R.C., and Vogt, C.A. (2005), "Residents' perceptions of community tourism impacts", Annals of Tourism Research, Vol. 32, No. 4, pp. 1056-1076.

Andereck, K.L., and Nyaupane, G.P. (2011), "Exploring the nature of tourism and quality of life perceptions among residents", Journal of Travel Research, Vol. 50, No. 3, pp. 248-260.

Andriotis, K. (2005), “Community groups' perceptions of and preferences for tourism development: Evidence from Crete", Journal of Hospitality \& Tourism Research, Vol. 29, No. 1, pp. 67-90 http://dx.doi.org/10.1177/1096348004268196.

Baggio, R. and Klobas, J. (2011), Quantitative methods in tourism: A handbook. Channel View Publications Bristol.

Bujosa, A., and Rosselló, J. (2007), "Modelling environmental attitudes toward tourism", Tourism Management, Vol. 28, pp. 688-695.

Choi, H.-S.C. and Sirakaya,E. (2005), "Measuring residents' attitude towards sustainable tourism: development of sustainable tourism attitude scale", Journal of Travel Research, Vol. 43, No. 4, pp. 380-394.

Cisneros-Martínez, J. D., and Fernandez-Morales, A. (2015), "Cultural tourism as tourist segment for reducing seasonality in a coastal area: The case study of Andalusia", Current Issues in Tourism, Vol. 18, No. 8 , pp. 765-784.

Croatian bureau of statistics (2018), http://www.dzs.hr/

Díaz, R. and Gutiérrez, D. (2010), "La actitud del residente en el destino turístico de Tenerife: evaluación y tendencia”, PASOS: Revista de Turismo y Patrimonio Cultural, Vol. 8, No. 4, pp. 431-444.

Đurkin, J., Perić, M., Kljaić Šebrek, J. (2017), “Addressing organisational challenges of cultural tourism in rural areas through community-based tourism model"', 4th International Scientific Conference ToSEE - Tourism in Southern and Eastern Europe 2017, Conference Proceedings, Vol. 4 , University of Rijeka, Faculty of Tourism and Hospitality Management, Opatija, pp. 145-157.

Gursoy, D., Chi, C.G., and Dyer, P. (2010), "Locals' attitudes toward mass and alternative tourism: the case of Sunshine Coast, Australia”, Journal of Travel Research, Vol. 49, No. 3, pp. 381-394. https://doi.org/10.1177/0047287509346853

Hanafiah, M.H,. Jamaluddin. M.R., and Zulkifly. M.I. (2013), "Local Community Attitude and Support towards Tourism Development in Tioman Island. Malaysia”, Procedia - Social and Behavioral Sciences, Vol. 105. pp.792-800. 
ToSEE - Tourism in Southern and Eastern Europe, Vol. 5, pp. 641-653, 2019

D. Soldić Frleta, J. Đurkin Badurina: FACTORS AFFECTING RESIDENTS' SUPPORT FOR ...

Institute for tourism Zagreb (2010), Assessment of Tourism Consumption in Zagreb in 2009, Viewed 15 February 2019

http://www.iztzg.hr/UserFiles/Pdf/Tomas/2010-Assessment-of-Tourism-Consumption-in-Zagrebin-2009-Summary.pdf

Jurowski, C., Uysal, M., and Williams, D.R. (1997), “A Theoretical Analysis of Host Community Resident Reactions to Tourism”, Journal of Travel Research, Vol. 34, No. 2, pp. 3-11. https://doi.org/10.1177/004728759703600202

King, B., Pizam, A and Milman, A. (1993), "Social Impacts of Tourism: Host Perceptions", Annals of Tourism Research, Vol. 20, No. 4, pp. 650-665.

Ko, D.W., and Stewart, W.P. (2002), “A structural equation model of residents' attitudes for tourism development”, Tourism Management, Vol. 23, pp. 521-530.

Kuvan, Y., and Akan, P. (2005), "Residents' attitudes toward general and forest-related impacts of tourism: The case of Belek Antalya", Tourism Management, Vol. 26, pp. 691-706. https://doi.org/10.1016/j.tourman.2004.02.019

Látková, P., and Vogt, C.A. (2012), "Residents' attitudes toward existing and future tourism development in rural communities", Journal of Travel Research, Vol. 51, No. 1, pp. 50-67. http://dx.doi.org/10.1177/0047287510394193.

Lee, T.H. (2013), "Influence analysis of community resident support for sustainable tourism development", Tourism Management, Vol. 34, pp. 37-46. https://doi.org/10.1016/j.tourman.2012.03.007

Long, P.H. and Kayat, K. (2011), "Residents' perceptions of tourism impact and their support for tourism development: the case study of Cuc Phuong National Park. Ninh Binh province. Vietnam", European Journal of Tourism Research, Vol. 4, No. 2, pp. 123-146.

Meimand, S.E,. Khalifah, Z., Zavadskas, E.K., Mardani, A., Najafipour, A.A. and Ahmad, U.N.U. (2017), "Residents' Attitude toward Tourism Development: A Sociocultural Perspective", Sustainability, Vol. 9, No. 7, pp. 1170. https://doi.org/10.3390/su9071170

McGehee, N.G. and Andereck, K.L. (2004), "Factors Predicting Rural Residents' Support of Tourism", Journal of Travel Research, Vol. 43, pp. 131-140. https://doi.org/10.1177/0047287504268234

Milano, C. (2017), Over-tourism and Tourism-phobia: Global trends and local contexts, Ostelea School of Tourism \& Hospitality. Barcelona

Nunkoo, R., and Gursoy, D. (2012), "Residents' support for tourism: an identity perspective", Annals of Tourism Research, Vol. 39, No. 1, pp. 243-268. https://doi.org/10.1016/j.annals.2011.05.006

Oviedo-Garcia, M.A., Castellanos-Verdugo, M., Martin-Ruiz, D. (2008), “Gaining residents' support for tourism and planning”, International Journal of Tourism Research, Vol. 10, pp. 95-109.

Perdue, R.R., Long, P.T., and Allen, L. (1987), "Rural Resident Tourism Perceptions and Attitudes." Annals of Tourism Research, Vol. 14, No. 3, pp. 420-29. https://doi.org/10.1016/0160-7383(87)90112-5

Ramseook-Munhurrun,P. and Naidoo, P. (2011), "Residents' attitudes toward perceived tourism benefits", International Journal of Management and Marketing Research, Vol. 4, No. 3, pp. 45-56.

Rasoolimanesh, S.M., Jaafar, M., Kock, N., and Ramayah, T. (2015), “A revised framework of social exchange theory to investigate the factors influencing residents' perceptions", Tourism Management Perspectives, Vol. 16, pp. 335-345.

Sanchéz-Cañizares. S., Nuñes-Tabales. J. and Fuentes-García, F. (2014), "Local residents' attitudes towards the impact of tourism development in Cape Verde", Tourism \& Management Studies, Vol. 10, No. 1, pp. 87-96.

Shin, Y. (2010), "Residents' perceptions of the impact of cultural tourism on urban development: The case of Gwangju, Korea", Asia Pacific Journal of Tourism Research, Vol. 15, No. 4, pp. 405-416.

Singh, D.R. and Wright, A. (2011), "Tourism and economic growth, the Jamaican experience" In I. Boxil (2011), Caribbean tourism perceptions, economic development and air travel, Centre for Tourism and Policy Research, The University of the West Indies, Mona, pp. 11-19.

Soldić Frleta, D. and Smolčić Jurdana, D. (2018), "Understanding tourist spending on culture and entertainment", Economic and Social Development: Book of Proceedings, 27th International Scientific Conference on Economic and Social Development - Rome, 1-2 March 2018, Varazdin Development and Entrepreneurship Agency (VADEA) pp. 448-461.

Stylidis, D., Biran, A.,Sit, J. and Szivas, E.M. (2014), "Residents' support for tourism development: The role of residents' place image and perceived tourism impacts", Tourism Management, Vol. 45, pp. 260274. http://dx.doi.org/10.1016/j.tourman.2014.05.006

Tokarchuk, O., Gabriele, R., and Maurer, O. (2017), "Development of city tourism and well-being of urban residents: A case of German magic cities", Tourism Economics, Vol. 23, No. 2, pp. 343-359.

Yoon, Y., Gursoy, D. and Chen, J.S. (2001), "Validating a tourism development theory with structural equation Modelling", Tourism Management, Vol. 22, pp. 363-372. https://doi.org/10.1016/S0261-5177(00)00062-5 
ToSEE - Tourism in Southern and Eastern Europe, Vol. 5, pp. 641-653, 2019

D. Soldić Frleta, J. Đurkin Badurina: FACTORS AFFECTING RESIDENTS' SUPPORT FOR ...

Zagreb Tourist Board (2018), Zagreb Visitor Survey 2017/18 Infographic Report, viewed 19 February 2019. http://www.infozagreb.hr/documents/b2b/STRZagrebVisitorSurvey.pdf

Wang, Y., and Pfister, R.E. (2008), "Residents' Attitudes toward Tourism and Perceived Personal Benefits in a Rural Community", Journal of Travel Research, Vol. 47, No. 1, pp. 84-93.

Word Tourism Organisation UNWTO (2018), UNWTO Tourism Highlights 2018 Edition, viewed February 19 2019. https://www.e-unwto.org/doi/pdf/10.18111/9789284419876

World Tourism organization UNWTO and IPSOS (2019), Global survey on the perception of residents towards city tourism: impact and measures, viewed 15 February 2019. http://www2.unwto.org/press-release/2019-01-25/first-ever-unwtoipsos-survey-citizensrecognize-positive-impact-tourism.

Daniela Soldić Frleta, PhD, Assistant Professor

University or Rijeka

Faculty of Tourism and Hospitality Management

Primorska 42, 51410 Opatija, Croatia

Phone: +385-51-294717

E-mail: danielas@fthm.hr

Jelena Đurkin Badurina, PhD, Assistant Professor

University or Rijeka

Faculty of Tourism and Hospitality Management

Primorska 42, 51410 Opatija, Croatia

Phone: +385-51-294188

E-mail: jelenad@fthm.hr 